\title{
ANALISIS KELAYAKAN FINANSIAL INDUSTRI KECIL GULA KELAPA (Studi Kasus di Kecamatan Kempas, Kabupaten Indragiri Hilir, Riau)
}

\author{
Hermiza Mardesci( ${ }^{(1)}$, Santosa $^{(2)}$, Novizar Nazir ${ }^{(3)}$, Rika Ampuh Hadiguna ${ }^{(4)}$ \\ ${ }^{(1)}$ Dosen Teknologi Pangan UNISI \\ mimzaaci@yahoo.co.id \\ ${ }^{(2)}$ Dosen Teknologi Pertanian Universitas Andalas Padang \\ santosa764@yahoo.co.id \\ (3) Dosen Teknologi Pertanian Universitas Andalas Padang \\ nazir_novizar@yahoo.com \\ ${ }^{(4)}$ Dosen Teknik Industri Universitas Andalas Padang \\ hadiguna10@gmail.com
}

\begin{abstract}
Abstrak
Penelitian ini bertujuan untuk mengetahui kelayakan industri kecil gula kelapa secara finansial. Penelitian dilaksanakan di Kecamatan Kempas Kabupaten Indragiri Hilir, Provinsi Riau, Indonesia. Dari 4 pengrajin gula kelapa yang terdapat di lokasi penelitian, digunakan dua pengrajin sebagai sampel. Analisis data yang digunakan yaitu untuk mengetahui proses produksi gula kelapa, dan untuk mengetahui kelayakan finansial industri kecil gula kelapa dengan menggunakan metode NPV, Net B/C Ratio, dan IRR. Hasil penelitian menunjukkan bahwa proses produksi gula kelapa meliputi penyadapan nira, penyaringan, pemasakan, pencetakan, dan pengemasan. Industri kecil gula kelapa ini layak dikembangkan berdasarkan analisis finansial. Nilai NPV sebesar 125.133,98 dengan diskon faktor $10 \%$, Net B/C Ratio sebesar 4,53 dan nilai IRR sebesar $42 \%$.
\end{abstract}

Kata Kunci : Gula kelapa, NPV, IRR, B/C ratio

\section{PENDAHULUAN}

Kelapa merupakan komoditas perkebunan yang memiliki banyak nilai ekonomis. Hampir semua bagian dari kelapa memiliki manfaat untuk berbagai keperluan. Daging buah kelapa dapat diolah menjadi kopra, virgin coconut oil (VCO), minyak kelapa, kelapa parut, santan, tepung kelapa. Sabut dapat diolah menjadi kerajinan tangan, matras, tali, jok mobil, genteng, karpet, cocofiber (serat sabut kelapa), dan cocopeat (serbuk sabut kelapa). Air kelapa dapat diolah menjadi nata de coco.

Tempurung dapat diolah menjadi tepung tempurung, asap cair, arang, dan karbon aktif. Tidak hanya buahnya, kelapa dapat juga dimanfaatkan niranya. Nira diperoleh dari tandan bunga, sehingga apabila kelapa menghasilkan nira maka kelapa tersebut tidak lagi menghasilkan buah. Nira diperoleh dari pohon kelapa dengan cara penderesan atau penyadapan. Nira kelapa dapat dimanfaatkan sebagai minuman segar seperti lahang, dapat dijadikan bioetanol, difermentasi secara alami menjadi tuak, 
dibuat menjadi cuka dengan cara dibiarkan selama 24 jam, dan nira kelapa yang diuapkan akan menghasilkan gula kelapa (Widayanti, 2011)

Indragiri Hilir merupakan salah satu Kabupaten di Riau yang menghasilkan cukup banyak kelapa. Menurut data statistik, produksi kelapa dalam di Indragiri Hilir mencapai $390.924,28$ ton per tahun dengan luas lahan 295.380,24 Ha. Untuk kelapa hybrida tercatat produksi sebanyak 67.055,69 ton dari luas lahan 28.770 ton. Dengan potensi tersebut membuat Kabupaten Indragiri Hilir tercatat sebagai salah satu daerah kelapa terbesar di dunia, bahkan dijuluki sebagai Tanah Hamparan Kelapa Dunia (Dishubkominfo Inhil, 2015). Pada tahun 2014, produksi kelapa dalam mencapai 566.755 Ton (Kabupaten Indragiri Hilir dalam Angka, 2015).

Salah satu daerah di Indragiri Hilir yang memproduksi gula kelapa adalah Kecamatan Kempas. Kempas dengan luas wilayah $364,49 \mathrm{~km}^{2}$ memiliki luas areal tanaman kelapa 6100 ha, dengan produksi kelapa pada 2014 sekitar $1200 \mathrm{~kg} / \mathrm{ha}$. Jumlah petani kelapa yang ada di Kempas ini adalah 1.245 orang. Sedangkan untuk kelapa hibrida, jumlah produksi pada tahun 21014 mencapai $1285 \mathrm{~kg} / \mathrm{ha}$, dengan jumlah petani 1.620 orang (Kabupaten Indragiri Hilir dalam Angka, 2015).

Industri gula kelapa di Kempas ini belum terlalu banyak. Selama ini gula kelapa hanya diproduksi di industri rumah tangga. Hal ini disebabkan karena, masyarakat belum mengetahui nilai ekonomis dari produksi gula kelapa. Oleh seba itu, maka perlu kajian untuk menentukan kelayakan produksi gula kelapa berdasarkan kelayakan finansial.

Berdasarkan uraian pada latar belakang, maka masalah yang dirumuskan adalah bagaimana proses produksi gula kelapa yang baik, dan apakah usaha gula kelapa layak untuk dikembangkan. Tujuan dari penelitian ini adalah mengetahui proses produksi gula kelapa, dan mengetahui kelayakan finansial usaha pengolahan gula kelapa.

\section{METODOLOGI PENELITIAN}

Penelitian dilaksanakan di Kecamatan Kempas, Kabupaten Indragiri Hilir, Provinsi Riau, Indonesia. Pemilihan lokasi ini berdasarkan pertimbangan bahwa di Kecamatan Kempas terdapat beberapa usaha produksi gula kelapa. Waktu yang diperlukan untuk memperoleh data sekitar 1 bulan, mulai Juli sampai Agustus 2016.

Penentuan responden berdasarkan pendapat Arikunto (2002) yang menyatakan apabila subyek kurang dari 100 lebih baik populasi diambil semua sebagai sampel, tetapi kalau lebih dari 100 maka dapat diambil sampel 10-15\% atau 20-25\%. Pada lokasi penelitian ini jumlah pengrajin gula kelapa sebanyak 4 Orang. Berdasarkan pendapat tersebut, jumlah sampel yang diambil dalam penelitian ini adalah sebesar 4 orang responden.

Data yang dikumpulkan pada penelitian ini ada dua jenis, yaitu data primer dan data sekunder. Data primer diperoleh dari wawancara dengan petani responden dengan kuisioner yang berhubungan dengan tujuan penelitian. Sedangkan data sekunder diperoleh dari instansi yang terkait yang dapat memberikan gambaran kondisi umum wilayah penelitian yaitu Dinas Perkebunan Indragiri Hilir, dan BPS Kabupaten Indragiri Hilir.

Berdasarkan data yang diperoleh, maka selanjutnya dianalisis secara kualitatif sebagai berikut:

1. Untuk mengetahui proses produksi gula kelapa di gambarkan secara 
deskriftif (analisis kualitatif) untuk mengungkapkan informasi tentang proses produksi gula kelapa kaitannya dengan prospek pengembangan usaha gula kelapa

2. Untuk mengetahui kelayakan finansial usaha pengolahan gula kelapa menggunakan analisis data sebagai berikut :

\section{Net Present Value (NPV)}

NPV merupakan perbedaan antara nilai sekarang dari manfaat dan biaya. Dengan demikian, apabila NPV bernilai posisitf maka dapat diartikan sebagai besarnya keuntungan yang diperoleh proyek NPV bernilai negatif menunjukkan kerugian. NPV dapat dihitung dengan persamaan sebagai berikut (Santosa, 2010) :

$$
N P V=\sum_{t=1}^{n} \frac{B t-C t}{(1+i)^{t}}
$$

Keterangan :

$$
\begin{aligned}
\mathrm{NPV}= & \text { Net Present Value }(\mathrm{Rp}) \\
\mathrm{Bt}= & \text { Aliran kas masuk pada tahun } \\
& \text { ke- } \mathrm{t}(\mathrm{Rp}) \\
\mathrm{Ct}= & \text { Aliran kas keluar pada tahun } \\
& \text { ke- } \mathrm{t}(\mathrm{Rp}) \\
\mathrm{n} & = \\
\mathrm{t} & \text { Umur ekonomi (tahun) } \\
= & \text { Tingkat suku bunga (\%/tahun) }
\end{aligned}
$$

\section{Net Benefit Cost Ratio (B/C ratio)}

$\mathrm{B} / \mathrm{C}$ ratio merupakan perbandingan antara keuntungan yang diterima dengan biaya yang dikeluarkan $\mathrm{B} / \mathrm{C}$ ratio ditentukan dengan persamaan (Santosa, 2010) :

$$
\mathrm{B} / \mathrm{C} \text { ratio }=\frac{\sum_{\mathrm{t}=1}^{n} \frac{B_{t}}{(1+i)^{t}}}{\sum_{\mathrm{t}=1}^{\mathrm{n}} \frac{C_{t}}{(1+i)^{t}}}
$$

Kriteria keputusan yang diambil dalam menentukan kelayakan berdasarkan B/C Ratio adalah : a. Jika B/C Ratio $\geq 1$, maka proyek dikatakan layak diterima;

b. Jika B/C Ratio< 1, maka proyek dikatakan tidak layak diterima.

\section{Internal Rate of Return (IRR)}

IRR merupakan nilai discount rate (i) yang membuat NPV sama dengan nol (Kadariah et al., 1999). IRR dihitung dengan menggunakan persamaan berikut (Santosa, 2010) :

$I R R=i_{1}+\left[\left(N P V_{1}\right)\left(i_{2}-i_{1}\right) /\left(N P V_{1}-N P V_{2}\right)\right]$

Penyelesaian persamaan tersebut dilakukan dengan menggunakan metode trial and error atau dengan teknik penelusuran oleh komputer untuk mencari nilai akar persamaan polinomial dalam $i$, dengan $i_{1}$ adalah tingkat suku bunga yang menyebabkan $\mathrm{NPV}_{1}$ bernilai positif, sedangkan $i_{2}$ merupakan tingkat suku bunga yang menyebabkan $\mathrm{NPV}_{2}$ bernilai negatif mendekati nol. Kriteria pembanding IRR adalah tingkat suku bunga yang berlaku (i) dan jika tingkat bunga $>\mathrm{i}$, maka keputusan yang diambil adalah layak.

\section{HASIL DAN PEMBAHASAN}

Identitas responden merupakan gambaran keadaan dan kondisi status responden dalam usahanya. Selain itu, identitas tersebut juga turut mempengaruhi proses produksi gula kelapa. Oleh sebab itu sebelum sampai pada pembahasan analisis kelayakan finansial, terlebih dahulu disajikan tentang identitas pengrajin gula kelapa yang terpilih sebagai responden dalam penelitian ini.

Usia dari responden dalam penelitian ini berkisar antara 30 sampai 50 tahun. Hal ini menunjukkan bahwa pengrajin gula kelapa di Kecamatan Kempas berada pada usia produktif. Usia produktif ini akan menjamin bahwa 
pengrajin tersebut memiliki kemampuan untuk mengolah gula kelapa. Hal tersebut sesuai dengan pendapat Kaslan Tohir (1991), umur yang ideal untuk pekerjaan fisik usahatani adalah antara 25 - 55 tahun, kerena pada usia tersebut petani memiliki kemampuan fisik yang optimal untuk mengerjakan pekerjaanpekerjaan fisik dalam usahatani. Itu sebabnya petani yang berumur kurang dari 25 tahun dikategorikan usia kurang produktif, usia $25-55$ tahun dikategorikan usia produktif dan usia lebih dari 55 tahun dikategorikan sebagai usia tidak produktif.

Salah satu faktor penentu dalam kematangan pola pikir seseorang adalah tingkat pendidikan yang telah mereka tempuh. Secara umum, orang dengan tingkat pendidikan tinggi cenderung membuka wawasannya terhadap inovasiinovasi baru dibanding mereka yang tingkat pendidikannya tergolong rendah. Hal itulah mengapa orang dengan tingkat pendidikan yang tinggi lebih banyak maju dibanding mereka yang pendidikannya rendah.

Hampir semua responden dalam penelitian ini memiliki tingkat pendidikan hanya sampai Sekolah Menengah Pertama. Hal tersebut menunjukkan bahwa pengrajin gula kelapa di kecamatan Kempas memiliki tingkat pendidikan yang masih rendah. Rendahnya tingkat pendidikan tersebut bisa menjadi salah satu kendala yang mengakibatkan usaha pengolahan gula kelapa kurang berkembang baik dari segi manajemen finansial maupun dari segi produksi. Sedangkan teknik pengolahan gula kelapa ini responden dapatkan dari keluarga yang lebih dulu menggeluti usaha tersebut. Hal ini sejalan dengan pendapat Hidayat (2007) bahwa pendidikan seseorang pada umumnya mempengaruhi cara berpikir dan bertindak orang tersebut. Pendidikan dapat membuat seseorang bisa menjaga cara mereka bekerja dan sikap mereka. Untuk menangani hal tersebut diperlukan pendidikan informal bagi para petani seperti penyuluhan, sarahsehan untuk meningkatkan pengetahuan petani tentang pengolahan gula kelapa yang lebih baik.

\section{Proses Produksi Gula Kelapa}

Pembuatan gula kelapa pada prinsipnya adalah proses penguapan atau pemekatan nira. Tahap-tahap proses pembuatan gula kelapa meliputi:

\section{Pengumpulan Nira}

Nira hasil sadapan dikumpulkan dalam jerigen besar (biasanya ukuran 10$20 \mathrm{~L}$ ), lalu sesegera mungkin dimasak untuk mencegah terbentuknya asam. Sisa pengawet yang mengumpul di ujung jeringen tidak diikutkan karena akan menghasilkan warna gula yang kurang baik.

\section{Penyaringan}

Sebelum dimasak, nira disaring terlebih dahulu untuk membuang kotoran-kotoran berupa bunga kelapa, lebah dan semut. Penyaringan ini menggunakan saringan dapur dengan kerapatan yang sangat kecil.

\section{Pemasakan}

Dilakukan pemasakan nira pada suhu $110{ }^{\circ} \mathrm{C}$. Pada saat mulai mendidih, kotoran halus akan terapung ke permukaan bersama-sama buih nira. Pendidihan selanjutnya akan menimbulkan busa nira yang meluapluap berwarna coklat kekuningkuningan, ditambahkan parutan kelapa agar nira tidak meluap. Bila nira sudah mengental, api dikecilkan dan pekatan nira tetap diaduk-aduk. Untuk mengetahui bahwa nira tersebut sudah masak atau belum, dilakukan pengujian 
kekentalan yaitu dengan cara meneteskan pekatan nira ke dalam air dingin. Bila tetasan tadi menjadi keras, pemasakan sudah cukup dan wajan segera diangkat dari tungku. Waktu yang diperlukan untuk memasak 25-30 liter nira kira-kira 4-5 jam.

Penambahan parutan kelapa dalam Supardi (1993) dinamakan "pamepes". Pamepes dapat berupa parutan kelapa, kemiri, atau minyak goreng, tergantung kebiasaan pengrajin. Penambahan pamepes tidak boleh terlalu banyak atau terlalu sedikit. Jika pamepes yang ditambahkan terlalu banyak (lebih dari 2 sendok makan parutan kelapa) gula menjadi lembek, sedangkan jika terlalu sedikit (kurang dari 1 sendok makan parutan kelapa) nira bisa meluap dan gula yang dihasilkan menjadi kembung dan mudah remuk. Pamepes yang biasanya ditambahkan adalah 1-2 tetes minyak kelapa atau 2 sendok makan parutan kelapa untuk kurang lebih 30 Liter nira.

\section{Pendinginan}

Untuk mempercepat proses pendinginan pekatan nira dilakukan pengadukan. Pengadukan dilakukan sampai suhunya turun menjadi sekitar $70^{\circ} \mathrm{C}$. pengadukan ini juga akan menyebabkan tekstur dan warna gula yang dihasilkan lebih baik dan cepat kering.

\section{Pencetakan}

Segera setelah suhu pekatan nira telah turun menjadi sekitar $70{ }^{\circ} \mathrm{C}$ maka dilakukan pencetakan. Pekatan nira dituangkan ke dalam cetakan setengah tempurung kelapa seperti mangkuk yang sebelumnya telah direndam dan dibasahi dengan air untuk mempermudah pelepasan setelah gula menjadi kering. Pelepasan gula dilakukan setelah gula mencapai suhu kamar.

\section{Pengemasan}

Gula yang telah dikeluarkan dari cetakan kemudian dibungkus dengan kantung plastik yang telah disediakan dan siap dijual.

\section{Analisis Biaya Usaha Gula Kelapa}

Biaya yang dikeluarkan petani dalam proses produksi sehingga menghasilkan produk disebut sebagai biaya produksi, yang meliputi biaya tetap (fixed cost) dan biaya variabel (variable cost). Biaya tetap adalah biaya yang jumlah penggunaannya tidak berpengaruh terhadap produksi yang dihasilkan, seperti biaya pajak lahan, pajak penghasilan, listrik dan lain sebagainya. Sedangkan biaya variabel adalah biaya yang jumlah penggunaannya berpengaruh terhadap produksi yang dihasilkan, yang meliputi biaya bahan baku, bahan tambahan/pelengkap, tenaga kerja, dan sebaginya. Selain itu, ada juga nilai penyusutan alat dalam usahatani yaitu peralatan-peralatan yang digunakan selama berusahatani dalam kurun waktu tertentu berkurang nilainya.

Secara umum biaya yang dibutuhkan dalam usaha pengolahan gula kelapa terdiri dari biaya investasi, biaya tidak tetap, biaya tetap dan nilai penyusutan alat.

\section{Biaya Investasi}

Biaya-biaya yang termasuk dalam biaya investasi pada usaha pengolahan gula kelapa adalah biaya pembuatan dapur dan pembelian peralatanperalatan lainnya yang dibutuhkan sebelum proses produksi. Total biaya investasi yang dikeluarkan sebesar Rp. 2.020.000, yang terdiri dari Rp. 295.000 biaya pembuatan tungku, dan Rp. 1.725.000 biaya pembelian peralatanperalatan yang digunakan untuk pengolahan gula kelapa. 


\section{Biaya Tetap}

Biaya tetap adalah biaya yang jumlah penggunaannya tidak berpengaruh terhadap produksi yang dihasilkan. Biaya-biaya yang termasuk dalam usaha gula kelapa adalah sewa pohon kelapa dan nilai penyusutan alat. Sewa pohon kelapa sebanyak 50 pohon dengan harga per pohonnya Rp. 200.000 per tahun. Sehingga total biaya sewa pohon kelapa adalah Rp. 10.000.000. Sedangkan total biaya penyusutan adalah Rp. 312.000. Jadi total biaya tetap untuk satu tahun pengolahan gula kelapa adalah Rp. 10.312.000.

\section{Biaya Tidak Tetap}

yang $\begin{array}{r}\text { Biaya tidak tetap adalah biaya } \\ \text { jumlah }\end{array}$ berpengaruh terhadap produksi yang dihasilkan seperti biaya bahan baku, bahan tambahan, tenaga kerja, dan sebagainya. Dalam usaha gula kelapa biaya tidak tetap terdiri dari biaya kayu bakar, dan biaya minyak tanah. Biaya kayu bakar adalah Rp. 1.500 .000 per bulan, dan biaya minyak tanah adalah Rp. 360.000 per bulan. Jadi total biaya tidak tetap dalam pengolahan gula kelapa adalah Rp. 1.860 .000 per bulan, atau setara dengan Rp. 22.320.000 per tahun.

\section{Net Present Value (NPV)}

NPV merupakan perbedaan antara nilai sekarang dari manfaat dan biaya. Dengan demikian, apabila NPV bernilai posisitf maka dapat diartikan sebagai besarnya keuntungan yang diperoleh proyek. NPV bernilai negatif menunjukkan kerugian. Dalam penelitian ini digunakan diskon faktor 10\%. Hasil analisis NPV menunjukkan nilai Rp. 125.133.983. Berdasarkan pada kriteria penilaian NPV yaitu suatu usaha dinyatakan layak apabila nilai NPV positif maka dapat katakan bahwa usaha gula kelapa yang dikelolah oleh pengrajin di Kecamatan Kempas adalah layak dan menguntungkan untuk diusahakan.

\section{B/C ratio}

$\mathrm{B} / \mathrm{C}$ ratio merupakan perbandingan antara keuntungan yang diterima dengan biaya yang dikeluarkan. Hasil analisis pada penelitian ini didapatkan nilai Present Value of Net Benefit sebesar Rp. 160.565.074 dan nilai Present Value of Net Cost adalah Rp. 35.431.091. Sehingga nilai $\mathrm{B} / \mathrm{C}$ ratio usaha gula kelapa pada penelitian ini adalah 4,53. Berdasarkan kriteria keputusan yang diambil dalam menentukan kelayakan, maka usaha gula kelapa ini memberikan keuntungan dan bisa dikatakan layak untuk dikembangkan oleh pengrajin gula kelapa di Kecamatan Kempas.

\section{IRR}

IRR merupakan nilai discount rate (i) yang membuat NPV sama dengan nol (Kadariah et al., 1999). Nilai IRR dinyatakan dalam bentuk persentase. Hasil analisis pada penelitian ini menunjukkan nilai NPV positif sebesar Rp. 2.410.782,9 pada discount factor $40 \%$ dan niai NPV negatif sebesar Rp.8.838.270 pada discount factor 50\%. Hasil analisis pada kedua nilai NPV dan discount factor ini diperoleh IRR sebesar $42 \%$. Nilai yang diperoleh ini lebih besar dari Opportunity Cost of Capital. Nilai $42 \%$ ini juga menunjukkan usaha gula kelapa di Kecamatan Kempas akan memberikan keuntungan sampai pada tingkat suku bunga $42 \%$. Berdasarkan kriteria penilaian bahwa suatu usaha menguntungkan apabila nilai IRR lebih besar dari Opportunity Cost of Capital maka dapat dikatakan usaha gula kelapa di Kecamatan Kempas adalah menguntungkan dan layak diusahakan. 


\section{KESIMPULAN}

Berdasarkan hasil penelitian pada usaha pengolahan gula kelapa di Kecamatan Kempas, maka dapat ditarik kesimpulan sebagai berikut :

1. Proses pembuatan gula kelapa pada prinsipnya adalah proses penguapan atau pemekatan nira. Tahap-tahap proses pembuatan gula kelapa meliputi pengumpulan nira, penyaringan, pemasakan, pencetakan, dan pengemasan.

2. Usaha gula kelapa di Kecamatan Kempas layak dikembangkan dari aspek finansial. Hal ini dapat dilihat dari hasil analisis finansial yang dilakukan di mana:

a. NPVnya positif yakni sebesar Rp. 125.133.983 dengan diskon faktor $10 \%$

b. Net $\mathrm{B} / \mathrm{C}$ ratio $=1$, yakni sebesar 4,53. Net B/C 1,22 ini menunjukkan bahwa usaha gula kelapa yang dikelola memberikan kentungan sampai 4,53 kali dari biaya yang dikeluarkan.

c. IRR tingkat bunga yang diisyaratkan yakni sebesar $42 \%$. Lebih besar dari diskon Opprotunity Cost of Capital.

\section{DAFTAR PUSTAKA}

Astri W. 2011. Evaluasi Kemitraan Antara PT. Samudra Jaya Abadi dengan Petani Pembuat Gula Kelapa Mitra di Kabupaten Ciamis. Skipsi. Departemen Agribisnis, Fakultas Ekonomi dan Manajemen, Institut Pertanian Bogor. Bogor.

Badan Pusat Statistik. 2015. Kabupaten Indragiri Hilir dalam Angka.

Arikunto, Suharmisi. 2002. Prosedur Penelitian. Rineka cipta. Jakarta.

Santosa. 2010. Evaluasi Finansial untuk Manager, dengan Software Komputer. Penerbit IPB Press. Bogor.

Kadariah, L. K., dan C. Gray. 1999. Pengantar Evaluasi Proyek. Jakarta: Lembaga Penerbit Fakultas Ekonomi Univesitas Indonesia. Jakarta.

Tohir, Kaslan A. 1991. Seuntai Pengetahuan Tentang Usahatani di Indonesia. Penerbit Bina Aksara, Jakarta.

Hidayat. 2007. Pendidikan masyarakat. CV Pustaka Baca, Surabaya.

Supardi, Dudi. 1993. Memperlajari Faktor-Faktor yang Mempengaruhi Kelunakan Gula Merah dari Nira Kelapa, Studi Kasus di Daerah Cianjur. Skripsi. Fakultas Teknologi Pertanian Institut Pertanian Bogor. Bogor. 